\author{
JAIME CUADRIELLO
}

INSTITUTO DE INVESTIGACIONES ESTÉTICAS, UNAM

\title{
Santiago Sebastián, 1931-1995
}

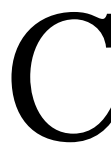

on profunda Pena, el Instituto de Investigaciones Estéticas comunica que el doctor Santiago Sebastián López murió el pasado jueves 9 de febrero en la ciudad de Valencia (España), a la edad de sesenta y cuatro años. Nació en una pequeña población rural del reino de Aragón (Villarquermado), el 25 de marzo de 1931. Licenciado por la Universidad Complutense de M adrid, ocupó distintas cátedras en las ciudades de Palma de $\mathrm{M}$ allorca, Córdoba, Barcelona y Cali (Colombia). En las últimas dos décadas se había radicado definitivamente en Valencia, en cuya universidad formó a valiosos especialistas en los campos de su interés. Realizó estancias académicas en las universidades de H eiderberg, Yale, y en el Fine Arts Institute de N ueva York. En repetidas ocasiones visitó nuestro país, tanto para impartir cursos como para ahondar en sus pesquisas, estrechando, así, un fructífero intercambio con algunos miembros de este instituto y con otros profesionales mexicanos dedicados al estudio de la arquitectura y la iconografía virreinales.

El doctor Sebastián perteneció a una notable generación de historiadores del arte formada bajo la figura patriarcal de don Diego Angulo Íñiguez; junto con Antonio Bonet Correa y Alfonso Pérez Sánchez, entre otros, representan para la historiografía española la primera hornada de profesionales con formación escolarizada y luego integrada a distintos claustros universitarios, en los cuales el examen del arte hispanoamericano siempre fue considerado parte de su labor docente.

D esde sus primeros trabajos académicos, el doctor Sebastián se distinguió - del resto de sus colegas y maestros - por los novedosos temas abordados y 
el enfoque iconológico aplicado en ellos. Armado con una erudición admirable y una memoria visual prodigiosa, conoció como pocos las fuentes gráficas y literarias del arte medieval, renacentista y barroco; y no solamente en el ámbito español, sino allende los Pirineo y el $O$ céano. $D$ e tal suerte, sus publicaciones fueron ampliamente reconocidas en toda H ispanoamérica; en ellas hizo importantes señalamientos desde la década de los sesenta, muchos de los cuales ahora comienzan a tener vigencia. Fue, además, un editor incansable de textos claves en la interpretación iconográfica: La fuga de Atalanta, el Bestiario de San Epifanio, los Emblemas de Alciato, Giovio, Vaenius, Solórzano y Pereira, N úñez de C epeda, etcétera. En plena madurez intelectual, cuando don Santiago daba forma a sus proyectos definitivos, le sobrevino una afección repentina y sorpresiva; a la cual, con su agudeza acostumbrada, puso por mote: "M i gozo se fue al pozo." D edicaba sus afanes al complejo universo de al emblemática, estrechando las correspondencias entre literatura y artes visuales. \$ 